\title{
NUTRIENT LOSS IN COMPOSTING OF AGROINDUSTRIAL RESIDUES
}

\section{LEOCIR J. CARNEIRO ${ }^{1}$, MÔNICA S. S. DE M. COSTA ${ }^{2}$, LUIZ A. DE M. COSTA ${ }^{3}$, MARCOS F. L. MARTINS ${ }^{4}$, MARCOS A. T. ROZATTI ${ }^{5}$}

\begin{abstract}
The management of composting may influence the characteristics of the produced compounds. The experiment used three frequencies of plowing, combined with the conditions: with and without coverage of the composting patio, with and without the use of commercial inoculant, resulting in 12 furrows, installed on the Experimental Center of Agricultural Engineering (NEEA), of the STATE UNIVERSITY OF WEST PARANÁ (UNIOESTE), Campus of Cascavel city - state of Paraná (PR), in Brazil. The waste and quantities used in kg were: corn cob (7.5); hatchery residue (5); floater sludge (31); ash (1); wheat cleaning residue (120); wheat pre-cleaning residue (120); corn peel (7.5); solid fraction of wash trucks used to transport chickens (2); solid fraction of pig manure (1) and coal (5), totaling 300kg of natural matter. The aim of this study was to evaluate the influence of plowings, patio coverage and inoculation in losses of $\mathrm{N}, \mathrm{P}, \mathrm{K}, \mathrm{Ca}, \mathrm{Mg}, \mathrm{Na}, \mathrm{Cu}, \mathrm{Zn}, \mathrm{Mn}$, Fe. The furrows plowed three times a week in the first month showed significant higher losses of $\mathrm{N}$ $(\mathrm{p}<0.05)$. The coverage of the composting patio influenced significantly the losses of $\mathrm{N}, \mathrm{K}, \mathrm{Mg}$ and $\mathrm{Na}(\mathrm{p}<0.05)$. The produced compounds had a high agronomic value in relation to macro and micronutrients. It is recommended the use of patio coverage and plowing twice a week in the first month and once a week in the subsequent months for a compound with higher concentrations of nutrients.
\end{abstract}

KEYWORDS: volatilization, leaching, inoculation, turn of plowing.

\section{PERDA DE NUTRIENTES NA COMPOSTAGEM DE RESÍDUOS AGROINDUSTRIAIS}

RESUMO: O manejo na compostagem pode influenciar nas características dos compostos produzidos. O experimento utilizou três frequências de revolvimentos, combinadas às condições: com e sem cobertura do pátio de compostagem; com e sem uso de inoculante comercial, resultando em 12 leiras, instaladas no Núcleo Experimental de Engenharia Agrícola (NEEA), pertencente à Universidade Estadual do Oeste do Paraná (UNIOESTE), Câmpus de Cascavel. Os resíduos e quantidades utilizadas em kg foram: sabugo de milho (7,5); resíduo de incubatório (5); lodo de flotador (31); cinza (1); resíduo da limpeza de trigo (120); resíduo da pré-limpeza de trigo (120); casquinha de milho $(7,5)$; fração sólida da lavagem de caminhões usados no transporte de frangos (2); fração sólida do dejeto de suínos (1), e carvão (5), perfazendo um total de $300 \mathrm{~kg}$ em matéria natural. Objetivou-se avaliar a influência dos revolvimentos, a cobertura do pátio e a inoculação nas perdas de $\mathrm{N}, \mathrm{P}, \mathrm{K}, \mathrm{Ca}, \mathrm{Mg}, \mathrm{Na}, \mathrm{Cu}, \mathrm{Zn}, \mathrm{Mn}$ e Fe. As leiras revolvidas três vezes por semana no primeiro mês apresentaram perdas de $\mathrm{N}$ significativamente maiores $(\mathrm{p}<0,05)$. A cobertura do pátio de compostagem influenciou significativamente nas perdas de $\mathrm{N}, \mathrm{K}, \mathrm{Mg}$ e $\mathrm{Na}(\mathrm{p}<0,05)$. Os compostos produzidos apresentaram alto valor agronômico em relação a macronutrientes e micronutrientes. Recomendam-se a utilização de cobertura do pátio e o revolvimento de duas vezes por semana, no primeiro mês, e uma vez nos meses subsequentes, para obter-se um composto com maior valor nutricional.

PALAVRAS-CHAVE: volatilização, lixiviação, inoculação, turno de revolvimento.

\footnotetext{
${ }^{1}$ Doutorando do Curso de Pós Graduação em Engenharia Agrícola - PGEAGRI/UNIOESTE.

${ }^{2}$ Docente dos Cursos de Graduação e Pós Graduação em Engenharia Agrícola da UNIOESTE - Campus de Cascavel.

${ }^{3}$ Bolsista RHAE/CNPq.

${ }^{4}$ Engenheiro Agrícola.

${ }^{5}$ Aluno do Curso de Engenharia Agrícola da UNIOESTE - Campus de Cascavel.

Recebido pelo Conselho Editorial em: 2-5-2012

Aprovado pelo Conselho Editorial em: 25-2-2013
} 


\section{INTRODUCTION}

The increase in agro-industrial production in recent years, and the lack of planning in the sector, has brought environmental problems related to the generation and improper disposal of waste.

Treatment methods are used to enable the reuse of these wastes in agriculture, in which the composting is well regarded by the scientific community because it eliminates pathogens, odors and visual pollution, and is considered a suitable alternative for waste disposal from the different agricultural, agro-industrial and industrial activities (COSTA et al., 2005).

Composting is a biological, aerobic, controlled process that allows the humification of organic matter obtaining as final product, the "organic compound" (MAGALHÃES et al., 2006).

At the beginning of composting, the organic matter, based on the ambient temperature, passes quickly through the mesophilic phase, reaching the thermophilic phase for a period of time. By continuing the process, the temperature falls and returns to the mesophilic phase (KIEHL, 2010).

The thermophilic phase, in which the temperature increases to a maximum value, is the phase in which occurs the destruction of pathogenic organisms and weed seeds, as they have low resistance to temperatures around 50 to $60^{\circ} \mathrm{C}$ (NEKLYUDOV et al., 2006). According to ORRICO JUNIOR et al. (2010), this phase is the most important when working with materials of animal origin, in which the destruction of the pathogens is critical for post application of the compound.

The composting is developed by micro-organisms, so it is affected by any factor that reaches microbiological activity, among the most important are the aeration, temperature, moisture content and C/N ratio (LANGSTON et al., 2002; MUKHTAR et al., 2004; VERAS \& POVINELLI, 2004; KIEHL, 2010).

Accordingly, the composting handling influences the quality of the produced compost. Furrows subjected to higher rates of aeration or frequent plowings shifts have higher $\mathrm{N}$ losses (HAO \& CHANG, 2001; RAVIV et al., 2004; PEIGNÉ \& GIRARDIN, 2005, BRITO et al., 2008; BERNAL et al., 2009, SHEN et al., 2011). While furrows managed on patios without coverage present leaching of nutrients, reducing the agronomic value of the produced compost (CEKMECELIOGLU et al., 2005; HAROUN et al., 2007).

The study aimed to assess the conditions of inoculation with Commercial Biological Product (CBP), coverage of composting patio and turn of plowing, seeking to ascertain the influence of these factors in the loss of nutrients of the furrows.

\section{MATERIAL AND METHODS}

The experiment was conducted at the Experimental Center of Agricultural Engineering (NEEA) belonging to the State University of West Paraná (UNIOESTE) - Campus of Cascavel city - state of Paraná (PR), in Brazil.

It was used the waste produced by COPACOL - Consolata Agricultural Cooperative, located in Cafelândia city - state of Paraná (PR), in Brazil. The furrows were formed by the quantity of each waste generated by the cooperative described by BERNARDI (2011). As the waste with higher production showed a lower amount of carbon, the residues from pre-cleaning and cleaning of grains were used in higher proportions to those produced by the company, to maintain the $\mathrm{C} / \mathrm{N}$ ratio of about 30/1 KIEHL (2010). The wastes and their quantities used in kg were: corn cobs (7.5); hatchery residue (5); floater sludge (31); ash (1); wheat cleaning residue (120); wheat pre-cleaning residue (120); corn peel (7.5); solid fraction of wash trucks used to transport chickens (2); solid fraction of pig manure (1) and coal (5), making a total of $300 \mathrm{~kg}$ of natural matter.

The residues were chemically characterized, with nutrient concentrations described in Table 1. 
TABLE 1. Chemical characterization of residues used in the furrow making.

\begin{tabular}{|c|c|c|c|c|c|c|c|c|c|c|c|c|}
\hline \multirow{2}{*}{ Residue } & $\mathrm{Fe}$ & $\mathrm{Zn}$ & $\mathrm{Cu}$ & $\mathrm{Mn}$ & $\mathrm{Na}$ & $\mathrm{Ca}$ & $\mathrm{Mg}$ & $\mathrm{K}$ & $\mathrm{P}$ & $\mathrm{C}$ & $\mathrm{N}$ & $\mathrm{C} / \mathrm{N}$ \\
\hline & \multicolumn{4}{|c|}{$\mathrm{mg} \mathrm{kg}^{-1}$} & \multicolumn{5}{|c|}{$\mathrm{g} \mathrm{kg}^{-1}$} & \multicolumn{2}{|c|}{$\%$} & \\
\hline Incubatory & 113.23 & 22.17 & 12.43 & 1.66 & 4.39 & 267.75 & 3.41 & 2.47 & 0.81 & 6.20 & 2.55 & 2.44 \\
\hline Sludge & $3,442.88$ & 184.57 & 36.81 & 51.37 & 3.82 & 2.74 & 0.40 & 1.00 & 3.34 & 10.20 & 6.81 & 1.50 \\
\hline Ash & $2,783.23$ & 305.39 & 107.33 & 2,199.21 & 5.08 & 230.02 & 19.40 & 186.21 & 4.72 & 0.00 & 0.05 & 0.00 \\
\hline Coal & $4,214.50$ & 99.13 & 158.43 & $1,187.52$ & 3.77 & 21.37 & 7.00 & 19.86 & 1.62 & 4.40 & 0.26 & 16.60 \\
\hline SFPW & $2,621.48$ & 856.57 & 771.50 & 458.02 & 13.23 & 23.14 & 5.24 & 6.54 & 5.95 & 37.27 & 2.50 & 14.91 \\
\hline SFTW & $3,734.36$ & 408.39 & 123.97 & 459.35 & 4.03 & 8.20 & 8.75 & 3.70 & 2.26 & 22.80 & 2.85 & 7.99 \\
\hline Peel & 478.24 & 47.00 & 11.20 & 39.32 & 2.77 & 0.53 & 0.83 & 5.29 & 0.42 & 62.30 & 1.24 & 50.47 \\
\hline Cob & 201.64 & 63.43 & 20.17 & 21.77 & 3.07 & 0.55 & 0.92 & 12.93 & 0.33 & 57.10 & 0.79 & 72.03 \\
\hline Bran & $1,554.05$ & 63.82 & 17.26 & 132.33 & 2.69 & 0.36 & 1.42 & 6.13 & 0.77 & 60.30 & 2.02 & 29.82 \\
\hline Chaff & 120.23 & 51.80 & 28.52 & 84.14 & 2.76 & 0.17 & 1.39 & 6.97 & 0.95 & 60.50 & 2.18 & 27.74 \\
\hline
\end{tabular}

SFPW = Solid fraction of pig waste; SFTW = Solid fraction of truck wash

After the installation of furrows, the residues were irrigated and stacked in a conical shape. The plowings were manual, with the aid of shovels, hoes and forks, throughout all the process. To keep the humidity around $60 \%$ it was added water to the furrows after each plowing.

Before each plowing, the tools and materials used for the plowing and sampling of furrows with CBP were washed with sanitary water diluted in water to avoid contamination with outside micro-organisms.

The CBP is a biological improver, which reduces the organic load and concentrations of $\mathrm{N}$ and $\mathrm{P}$ waste and odors. Composed by Yarrowia lipolytica at a concentration of $5.5 \times 10^{6} \mathrm{UFC}^{-g^{-1}}$, Bacillus subtilis, Bacillus licheniformis, Bacillus polymyxa at a concentration of $3.5 \times 10^{6} \mathrm{UFC}^{-1} \mathrm{~g}^{-1}$ (BIOPLUS, 2011).

According to recommendations of the company, the amount used was $20 \mathrm{~mL} \mathrm{~m}^{-3}$ week $^{-1}$. The CBP was diluted in 10L of water and applied with a watering can, while the furrows were plowed to provide homogeneous distribution.

It was installed 12 treatments, consisting of the combination of three frequencies of plowings (F1, F2, F3), two climatic conditions (C1, C0) with and without the use of CBP (B1, B0). The frequencies F1, F2 and F3 corresponding to plowings 1, 2 and 3 times a week during the first month. In the second month, the plowings were twice a week for F3 and once a week for the remaining frequencies of plowing. In the months following the furrows were plowed once a week. Table 2 describes the treatments used in the experiment.

TABLE 2. Description of the treatments used in the experiment.

\begin{tabular}{ccc}
\hline Furrow & Treatment & Description \\
\hline 1 & F1C1B0 & Frequency: once a week; Condition: covered; CBP: without \\
2 & F2C1B0 & Frequency: twice a week; Condition: covered; CBP: with \\
3 & F3C1B0 & Frequency: 3 times a week; Condition: covered; CBP: without \\
4 & F1C1B1 & Frequency: once a week; Condition: covered; CBP: with \\
5 & F2C1B1 & Frequency: twice a week; Condition: covered; CBP: with \\
6 & F3C1B1 & Frequency: 3 times a week; Condition: covered; CBP: with \\
7 & F1C2B0 & Frequency: once a week; Condition: uncovered; CBP: without \\
8 & F2C2B0 & Frequency: twice a week; Condition: uncovered; CBP: without \\
9 & F3C2B0 & Frequency: 3 times a week; Condition: uncovered; CBP: without \\
10 & F1C2B1 & Frequency: once a week; Condition: uncovered; CBP: with \\
11 & F2C2B1 & Frequency: twice a week; Condition: uncovered; CBP: with \\
12 & F3C2B1 & Frequency: 3 times a week; Condition: uncovered; CBP: with \\
\hline
\end{tabular}


To determine the nutrients, samples from various points of the furrow were taken, during the plowings, which were homogenized and taken for refrigerated packaging in LARSA (Analytical Laboratory of Agro-Industrial Solid Waste), belonging to UNIOESTE. The total N was determined at 7, 28, 56 days and at the end of the composting process, according to the methodology described in MALAVOLTA et al. (1989). The other macro and micronutrients were determined at the beginning and at the end of the process. It was determined the levels of Phosphorus (P) by spectrometry, according to MALAVOLTA et al. (1989), Potassium (K), Calcium (Ca), Magnesium (Mg), Sodium ( $\mathrm{Na})$, Zinc (Zn), Copper (Cu), Iron (Fe) and Manganese (Mn) in atomic absorption spectrometry after nitro-perchloric digestion (EMBRAPA, 1999).

It was conducted multiple regression analysis of the reductions of the elements $\mathrm{N}, \mathrm{P}, \mathrm{K}, \mathrm{Ca}$, $\mathrm{Mg}$ and $\mathrm{Na}$, due to the factors, plowings, inoculation with CBP and coverage of the composting patio. The number of plowings recorded for analysis referred to plowings made during the first 60 days of composting (active phase of degradation). For example, in the frequency F1 with one plowing per week, in an eight week period, results in eight plowings. For frequencies F2 and F3, the number of plowings in the first eight weeks was 12 and 20 respectively.

The use of the active phase time for degradation in the calculation of the number of plowings enables the comparison between treatments in view of the difference in time of composting. The treatments with the higher number of plowings had shorter composting time (70 to 80 days), whereas the furrows plowed once a week had longer composting time (90 to 105 days).

It was conducted residual analysis, auto correlation serial test of errors (Durbin-Watson) and normality of errors, aiming at meeting the assumptions of the generated models.

\section{RESULTS AND DISCUSSION}

\section{Losses of $\mathbf{N}$}

The $\mathrm{N}$ contents were expressed in percentage of dry matter. As $\mathrm{C}$ losses are generally higher than the $\mathrm{N}$ losses, it is natural that the concentration of the second element increase during the composting process. However, multiplying the $\mathrm{N}$ percentage by the dry mass of the furrow, it was obtained the amount of this nutrient in kilograms, to facilitate interpretation (Figure 1).

A

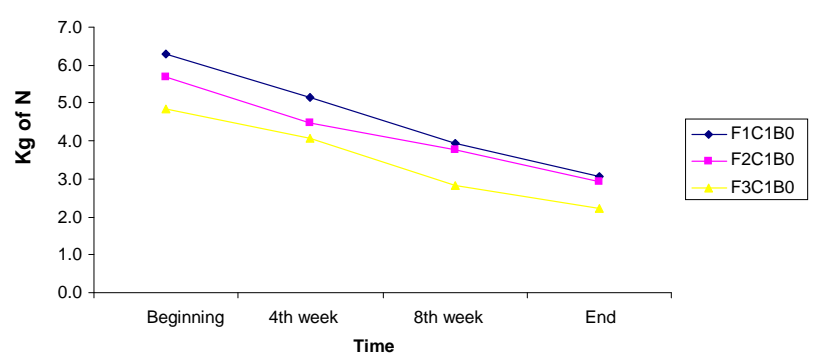

C

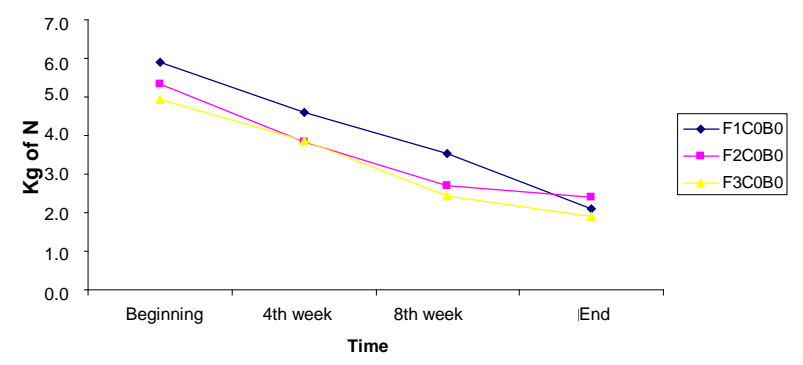

B

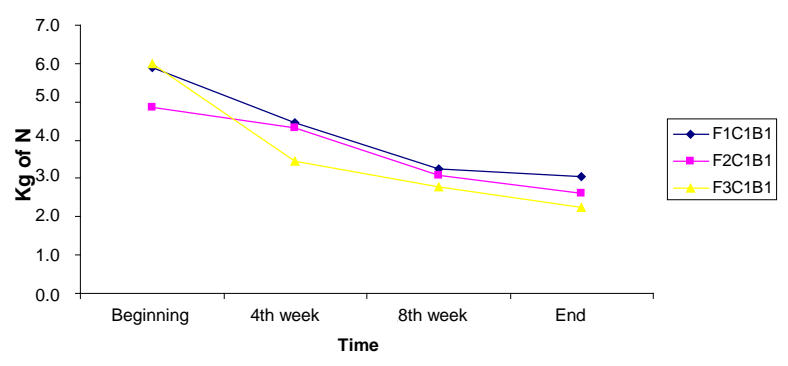

D

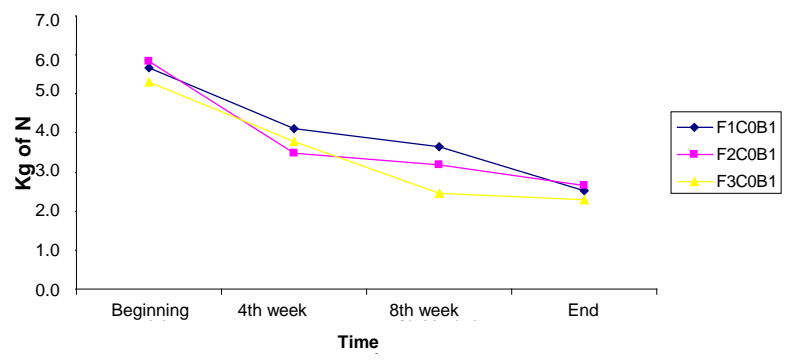

FIGURE 1. Nitrogen amount in the covered furrows without CBP (A) and with CBP (B), uncovered without CBP (C) and with CBP (D). 
The initial values were between 5 and $6 \mathrm{~kg}$ of $\mathrm{N}$ per furrow, at the end of the experiment remained 2 to $3 \mathrm{~kg}$ per furrow, representing reductions ranging from 45 to $65 \%$.

The highest reductions occurred in the external furrows, being observed in the treatment F1C0B0 the highest loss of $\mathrm{N}(64.43 \%)$. The lowest losses were recorded in F2C1B0, F1C1B0 and F2C1B1 of 48.53, 48.21 and 46.35\%, respectively. DAS et al. (2002) reported reductions of 63.2 and $55.2 \%$ in the hatchery waste composting, with and without addition of broiler litter, respectively.

The results corroborate BERNARDI (2011), who found reductions from 48.0 to $66.4 \%$, working with the same residues but with a smaller quantity of plant material, resulting in a $\mathrm{C} / \mathrm{N}$ ratio inferior than 10:1. The increment of plant material in this study (residue of cleaning and precleaning of grains), provided the increase of $\mathrm{C} / \mathrm{N}$ ratio, and the initial values were around 15:1.

In general, the reductions of $\mathrm{N}$ were lower in furrows plowed twice a week in the first month (F2), followed by furrows plowed once a week (F1). The furrows with the highest losses were plowed three times a week (F3). It was expected that in F2 occurred higher losses than obtained in F1. However, frequent plowings in the first month resulted in lower temperatures in this period, reducing losses.

According to PAGANS et al. (2006), the losses of ammonia in composting are highly dependent of temperature, being exponentially during the thermophilic phase and linear during the mesophilic phase. LI et al. (2008) and GUARDIA et al. (2010a) reported that excessive aeration rates provide low temperatures, ineffective in eliminating pathogens, but effective in controlling the emission of gases and odors.

Because of this, the regression analysis according to the plowings did not return significant models. To enable analysis of the frequencies, it was created two dummy variables, which a combination of $(0,0)$ represents $F 1,(0,1)$ represents $F 2$ and $(1,1)$ represents the frequency of three plowings per week.

It was calculated the model initially with four variables of dummy type, two representing combinations of plowings and the other two representing inoculum and coverage. We found that the inoculum was not significant, so it was removed from the model, being the same summarized:

in which,

$$
\mathrm{RN}=57.9+7.75 \mathrm{R} 1-3.78 \mathrm{R} 2-6.12 \mathrm{C}
$$

$\mathrm{RN}=$ Reduction of Nitrogen;

R1 = Variable dummy 1;

R2 = Variable dummy 2;

$\mathrm{C}=$ Coverage.

According to the data presented in Table 3, the model was significant $(\mathrm{p}<0.05)$ and there was no lack of adjustment of the data $(\mathrm{p}>0.05)$. The coefficient of determination was considered good, so the model explains well the behavior of the data.

TABLE 3. ANOVA and lack of fit test of the adjustment model of nitrogen loss.

\begin{tabular}{|c|c|c|c|c|c|c|c|c|}
\hline $\begin{array}{l}\text { Source of } \\
\text { variation }\end{array}$ & GL & SQ & $\mathrm{QM}$ & $\mathrm{F}$ & p-value & $\mathrm{R}^{2}(\%)$ & $\begin{array}{c}\mathrm{R}^{2} \mathrm{Max} \\
(\%)\end{array}$ & $\begin{array}{c}\mathrm{R}^{2} \text { corrected } \\
(\%)\end{array}$ \\
\hline Regression & 3 & 232.41 & 77.47 & 4.36 & $0.042^{*}$ & 62.1 & 75.05 & 82.75 \\
\hline Residue & 8 & 142.02 & 17.75 & & & & & \\
\hline $\begin{array}{l}\text { Lack of } \\
\text { adjustment }\end{array}$ & 2 & 48.61 & 24.30 & 1.56 & $0.285^{\mathrm{ns}}$ & & & \\
\hline Pure error & 6 & 93.42 & 15.57 & & & & & \\
\hline Total & 11 & 374.43 & & & & & & \\
\hline
\end{tabular}


Applying the model values for the covered condition, the $\mathrm{N}$ reductions are 53.58, 57.55 and 49.8\% for F1, F2 and F3, respectively. For the uncovered condition, the reductions are 59.7, 55.92 and $63.67 \%$ for F1, F2 and F3, respectively. Therefore, the use of frequency F2 reduced losses of nitrogen by 13.5 and $12.2 \%$ for covered and uncovered conditions, respectively, compared to frequency F3. While the use of composting covered patio reduces $\mathrm{N}$ losses by $10.3,10.9$ and $9.6 \%$ for F1, F2 and F3, respectively.

PARKINSON et al. (2004) found similar results in bovine manure composting: reductions of 24.7, 30.4 and 36.8\% for non-plowed furrows, plowed once a week and plowed three times a week, respectively.

$\mathrm{N}$ losses occur mainly in the form of $\mathrm{NH}_{3}$ (TEJADA et al., 2001; PARKINSON et al., 2004; PAILLAT et al., 2005), reaching 60, 58 and 46\% for composting of pig manure, broiler litter and cattle manure, respectively (BERNAL et al., 2009).

MICHEL JUNIOR et al. (2004) reported reductions ranging from 7 to $38 \%$ in the cattle manure composting with sawdust and straw, while the losses of $\mathrm{N}$ had a negative correlation with $\mathrm{C} / \mathrm{N}$ ratio of the pile. TIQUIA \& TAM (2002) reported reductions of $58 \%$ in broiler litter composting under forced aeration. Reductions of 30\% were observed by BUSTAMANTE et al. (2008), in the sugarcane bagasse composting with broiler litter and cattle manure.

$\mathrm{N}$ losses are closely linked to the amount of biodegradable $\mathrm{C}$ present in the waste (LIANG et al., 2006; BERNAL et al., 2009; GUARDIA et al., 2010b). GUARDIA et al. (2010b) found reductions of less than $8.5 \%$ for solid fraction of pig manure mixed with wood scraps, while for household waste and sludge from slaughtered pigs, losses ranged from 36.7 to $66.2 \%$. Losses were in the majority, in the forms of $\mathrm{NH}_{3}, \mathrm{~N}_{2}$ and $\mathrm{N}_{2} \mathrm{O}$. The leaching losses were higher in sludge composting of slaughter pig. According to BERNAL et al. (2009), the leaching losses are easily controlled with proper maintenance of humidity of the pile, coverage composting patio and grease recirculation.

Many researchers have tried to reduce losses by ammonia volatilization in composting using different materials or waste: struvite (JEONG \& KIM, 2001; REN et al., 2010; FUKUMOTO et al., 2011), sawdust and potassium hydrogen phosphate (HU et al., 2007), bulking agents (JOLANUN \& TOWPRAYOON, 2010; DOUBLET et al., 2011), $\mathrm{Mg}$ and $\mathrm{PO}_{4}$ (LEE et al., 2009) and mature compost (AL-JABI et al., 2008; HAO et al., 2011). Although some of these techniques reduce ammonia emissions significantly, the amount released into the atmosphere is still great. Therefore, techniques for reducing emissions, grease recirculation and recovery of emitted gases form the next step in the evolution of composting.

\section{Losses of P, K, Mg, Ca and $\mathrm{Na}$}

The mineral contents tend to increase with the passage of the composting process due to the high losses of C (TIQUIA \& TAM, 2002). However, nutrient leaching can occur, especially in uncovered furrows (CEKMECELIOGLU et al. 2005). The quantities of minerals shown in Table 4 were calculated by multiplying the concentration of each nutrient by the furrow mass, to obtain values in $\mathrm{kg}_{\text {furrow }}{ }^{-1}$.

Observing Table 4, it is possible to diagnose influence of the coverage at final concentrations for all minerals, except for $\mathrm{P}$ and $\mathrm{Ca}$. The uncovered furrows received natural rainfall that caused leaching of minerals. In later stages of the composting process, from 60 days, the fibrous material has been degraded, allowing ingress of water more easily in the compost pile, which could increase the leaching losses. Moreover, the organic matter is mostly humified, strongly retaining ions to their colloids. Therefore, the loss of nutrients by leaching is subjected to the period in which the composting process is, as well as the rainfall during the period, the composition of the used waste and the organic matter humification. 
TABLE 4. Initial and final quantities of $\mathrm{P}, \mathrm{K}, \mathrm{Mg}$, $\mathrm{Ca}$ and $\mathrm{Na}$ in the composting furrows.

\begin{tabular}{lllllllllll}
\hline & \multicolumn{9}{c}{ Initial } & \multicolumn{9}{c}{ Final } \\
\cline { 2 - 12 } Treatment & $\mathrm{P}$ & $\mathrm{K}$ & $\mathrm{Mg}$ & $\mathrm{Ca}$ & $\mathrm{Na}$ & $\mathrm{P}$ & $\mathrm{K}$ & $\mathrm{Mg}$ & $\mathrm{Ca}$ & $\mathrm{Na}$ \\
\cline { 2 - 11 } & & & & \multicolumn{3}{c}{$\mathrm{kg}^{-1}$ furrow } \\
F1C1B0 & 0.50 & 1.71 & 0.45 & 3.92 & 0.57 & 0.20 & 1.42 & 0.39 & 1.26 & 0.10 \\
F2C1B0 & 0.45 & 1.63 & 0.38 & 1.35 & 0.62 & 0.21 & 1.19 & 0.40 & 1.13 & 0.07 \\
F3C1B0 & 0.37 & 1.27 & 0.30 & 1.44 & 0.64 & 0.19 & 1.21 & 0.36 & 1.42 & 0.08 \\
F1C1B1 & 0.49 & 1.77 & 0.48 & 3.10 & 0.60 & 0.24 & 1.37 & 0.45 & 1.35 & 0.12 \\
F2C1B1 & 0.38 & 1.36 & 0.33 & 1.30 & 0.59 & 0.19 & 1.16 & 0.37 & 1.22 & 0.07 \\
F3C1B1 & 0.47 & 1.73 & 0.42 & 4.47 & 0.62 & 0.20 & 1.33 & 0.37 & 0.88 & 0.08 \\
F1C0B0 & 0.43 & 1.49 & 0.37 & 0.53 & 0.66 & 0.17 & 0.75 & 0.27 & 0.75 & 0.05 \\
F2C0B0 & 0.43 & 1.53 & 0.38 & 1.25 & 0.60 & 0.19 & 0.95 & 0.30 & 1.00 & 0.07 \\
F3C0B0 & 0.37 & 1.21 & 0.33 & 0.92 & 0.76 & 0.17 & 0.83 & 0.28 & 0.97 & 0.06 \\
F1C0B1 & 0.37 & 1.23 & 0.34 & 0.24 & 0.64 & 0.19 & 0.96 & 0.32 & 0.76 & 0.07 \\
F2C0B1 & 0.42 & 1.48 & 0.42 & 0.55 & 0.81 & 0.19 & 1.07 & 0.31 & 0.66 & 0.08 \\
F3C0B1 & 0.39 & 1.36 & 0.34 & 0.39 & 0.62 & 0.20 & 0.90 & 0.30 & 0.51 & 0.06 \\
\hline
\end{tabular}

In order to test the significance of the coverage losses of minerals, it was held regression analysis of each element losses by the plowings, inoculum and coverage of the composting patio (Table 5).

The coverage influenced the losses of $\mathrm{K}, \mathrm{Mg}$ and $\mathrm{Na}(\mathrm{p}<0.05)$. It is observed in Table 5 that the values of betas respective to the variable coverage were negative for $\mathrm{K}, \mathrm{Mg}$ and $\mathrm{Na}$, respectively. These negative values indicate that the use of the composting patio reduces losses of specified elements. For example, for the condition without inoculum, with weekly plowings (F1), the reduction of $\mathrm{K}$ would be 22.28 and $37.83 \%$ for the covered and uncovered conditions, respectively. Therefore, the composting in covered patio reduces losses in 41.11, 86.64 and 5.40\% for $\mathrm{K}, \mathrm{Mg}$ and $\mathrm{Na}$, respectively.

TABLE 5. Analysis of the regression parameters corresponding to the losses variables of $\mathrm{P}, \mathrm{K}, \mathrm{Mg}$, $\mathrm{Ca}$ and $\mathrm{Na}$.

\begin{tabular}{cccccccccccc}
\hline \multirow{2}{*}{ Parameter } & \multicolumn{3}{c}{$\mathrm{P}$} & \multicolumn{3}{c}{$\mathrm{K}$} & \multicolumn{2}{c}{ Mg } & \multicolumn{2}{c}{ Ca } & \multicolumn{2}{c}{ Na } \\
\cline { 2 - 10 } & Betas & pvalue & Betas & pvalue & Betas & pvalue & Betas & pvalue & Betas & pvalue \\
\hline Intercept & 58.17 & $0.00^{*}$ & 40.95 & $0.00^{*}$ & 27.31 & $0.03^{*}$ & -77.21 & $0.24^{\text {ns }}$ & 88.40 & $0.00^{*}$ \\
Plowing & -0.21 & $0.41^{\text {ns }}$ & -0.39 & $0.49^{\text {ns }}$ & -0.71 & $0.32^{\text {ns }}$ & 3.25 & $0.42^{\text {ns }}$ & 0.21 & $0.16^{\text {ns }}$ \\
Coverage & -0.25 & $0.92^{\text {ns }}$ & -15.55 & $0.01^{*}$ & -18.74 & $0.02^{*}$ & 87.36 & $0.05^{\text {ns }}$ & -4.85 & $0.00^{*}$ \\
Inoculum & -3.37 & $0.19^{\text {ns }}$ & -4.16 & $0.45^{\text {ns }}$ & -0.38 & $0.96^{\text {ns }}$ & -30.79 & $0.45^{\text {ns }}$ & -1.32 & $0.36^{\text {ns }}$ \\
\hline ns = non significative at $5 \% ; *=$ significative at $5 \%$. & \multicolumn{4}{c}{ a }
\end{tabular}

The use of composting patio coverage proves once again an important factor to reduce nutrient losses by leaching. Besides reducing the agronomic value of produced compost, leaching causes problems of contamination of surface and groundwater (FRIGO et al., 2006; ANAMI et al., 2007; BAUMGARTNER et al., 2007; SAMPAIO et al., 2007; ANAMI et al., 2008; DAL BOSCO et al, 2008; PELISSARI et al., 2009; SAMPAIO et al., 2010; CARNEIRO et al., 2011).

\section{Concentrations of $\mathrm{Zn}, \mathrm{Cu}, \mathrm{Fe}$ and $\mathrm{Mn}$}

Although heavy metals are not lost in composting, except for leaching, they can be complexed to organic matter, reducing their mobility (HAROUN et al., 2007; WANG et al., 2010; KANG et al., 2011). Table 6 shows the initial and final concentrations of $\mathrm{Zn}, \mathrm{Cu}, \mathrm{Fe}$ and $\mathrm{Mn}$ of the 12 treatments. 
TABLE 6. Initial and final concentrations of $\mathrm{Zn}, \mathrm{Cu}, \mathrm{Fe}$ and $\mathrm{Mn}$ in the composting furrows.

\begin{tabular}{lcccccccc}
\hline & \multicolumn{4}{c}{ Initial } & \multicolumn{5}{c}{ Final } \\
\cline { 2 - 9 } Treatment & Zn & Cu & Fe & Mn & Zn & Cu & Fe & Mn \\
\cline { 2 - 9 } & & & \multicolumn{7}{c}{$\mathrm{mg} \mathrm{kg}^{-1}$} \\
F1C1B0 & 103.2 & 22.58 & 9350.40 & 226.90 & 372.86 & 51.97 & 16945.31 & 519.82 \\
F2C1B0 & 93.53 & 11.38 & 3480.98 & 167.09 & 437.67 & 46.20 & 16017.58 & 597.65 \\
F3C1B0 & 72.28 & 8.04 & 2748.63 & 132.47 & 363.20 & 33.47 & 12526.37 & 555.86 \\
F1C1B1 & 96.13 & 12.68 & 6028.29 & 280.78 & 351.26 & 35.50 & 18532.23 & 661.24 \\
F2C1B1 & 66.97 & 3.59 & 4245.17 & 142.90 & 263.14 & 30.07 & 17274.90 & 580.13 \\
F3C1B1 & 84.45 & 4.83 & 3480.98 & 174.92 & 248.36 & 31.26 & 17519.04 & 737.60 \\
F1C0B0 & 86.61 & 1.74 & 3608.35 & 181.13 & 300.66 & 15.99 & 15346.19 & 704.02 \\
F2C0B0 & 101.5 & 3.00 & 3098.88 & 191.33 & 340.46 & 57.57 & 11073.73 & 728.34 \\
F3C0B0 & 88.32 & 3.40 & 3045.82 & 165.19 & 210.28 & 77.59 & 12819.34 & 726.88 \\
F1C0B1 & 74.43 & 9.90 & 1591.73 & 176.72 & 138.65 & 60.54 & 7448.24 & 684.86 \\
F2C0B1 & 84.08 & 6.87 & 5986.04 & 187.39 & 99.99 & 79.63 & 26979.49 & 745.16 \\
F3C0B1 & 73.23 & 8.04 & 2600.04 & 145.51 & 55.65 & 71.74 & 26295.90 & 704.72 \\
\hline
\end{tabular}

The final concentrations of $\mathrm{Zn}, \mathrm{Cu}, \mathrm{Fe}$ and $\mathrm{Mn}$ were higher than for all initial treatments, corroborating with TIQUIA \& TAM (2002) and BERNARDI (2011). The values of Cu and Zn are within the maximum concentrations reported in the Austrian standard, one of the strictest. Maximum values are 500 and $2000 \mathrm{mg} \mathrm{kg}^{-1}$ for $\mathrm{Cu}$ and $\mathrm{Zn}$, respectively.

HAROUN et al. (2007) reported reductions of 11.8 and $16.0 \%$ on the final quantity of zinc and copper, respectively, in the tannery sludge composting, indicating leaching of nutrients. Although reductions in the amounts of metals are small, only $2 \%$ is considered available for plant absorption (AMIR et al. 2,005; HAROUN et al. 2007).

Therefore, although the concentration of metals increases during composting, these elements are, for the most part, in the unavailable form to plants and compost quality is not affected by these concentrations.

The study showed that composting is a system for treating solid waste efficiently, although there is loss of nutrients, the remaining amount is sufficient for use as soil broker and supply nutrients to plants confirming results obtained by LIANG et al. (2006) and BERNARDI (2011).

\section{CONCLUSIONS}

Based on the obtained results it can be concluded:

Furrows plowed twice a week in the first month and once a week in the remaining months had lower nitrogen losses.

The composting patio coverage is an important factor to decrease the losses of $\mathrm{K}, \mathrm{Mg}, \mathrm{Na}$ and N.

The use of CBP in the composting had no influence on losses of the studied nutrients. It was emphasize that more detailed studies on the application of this product residues should be performed, since the high temperatures of the composting may have inhibited the microorganisms constituents of the product.

The produced compounds were of high quality and agronomic value in relation to the contents of N, P, K, Mg, Ca, Na, Cu, Zn, Fe and Mn, and can be used as organic fertilizers.

\section{ACKNOWLEDGEMENTS}

The Coordination for the Improvement of Higher Level Personnel - CAPES for the financial support and the COPACOL for the residue cession. 


\section{REFERENCES}

AL-JABI, L. F.; HALALSHEH, M. M.; BADARNEH, D. M. Conservation of ammonia during food waste composting. Environmental Technology, London, v. 29, p. 10, 2008.

AMIR, S.; HAFIDI, M.; MERLINA, G.; REVEL, J. C. Sequential extraction of heavy metals during composting of sewage sludge. Chemosphere, Oxford, v. 59, p. 801-810, 2005.

ANAMI, M. H.; SAMPAIO, S. C.; SUSZEK, M.; GOMES, S. D.; QUEIROZ, M. M. F.

Deslocamento miscível de nitrato e fosfato proveniente de água residuária da suinocultura em colunas de solo. Revista Brasileira de Engenharia Agrícola e Ambiental, Campina Grande, v. 12, n. 1, p. 75-80, 2008.

ANAMI, M. H.; SAMPAIO, S. C.; FRIGO, E. P.; SUSZEK, M. Lixiviação de nitrato e fosfato proveniente de água residuária da suinocultura tratada em sistema de lagoas. Revista Irriga, Botucatu, v. 12, n. 2, p. 192-201, 2007.

BAUMGARTNER, D.; SAMPAIO, S. C.; SILVA, T. R.; TEO, C. R. P. A.; VILAS BOAS, M. A. Reuso de águas residuárias da piscicultura e da suinocultura na irrigação da cultura da alface. Engenharia Agrícola, Jaboticabal, v. 27, n. 1, p. 152-163, 2007.

BERNAL, M.P; ALBURQUERQUE, J.A.; MORAL, R. Composting of animal manures and chemical criteria for compost maturity assessment. A review. Bioresource Technology, St. Joseph, v. 100, p. 5444-5453, 2009.

BERNARDI, F. H. Compostagem de resíduos agroindustriais: Incubatório. 2011. (Dissertação de Mestrado em Engenharia Agrícola) - Centro de Ciências Exatas e Tecnológicas, Universidade Estadual do Oeste do Paraná, Cascavel, 2011.

BIOPLUS. Patentes. Disponível em: <www.bioplus.ind.br>: Acesso em: 22 fev. 2011.

BRITO, L.M; AMARO, A.L; MOURÃO, I; COUTINHO, J. Transformação da matéria orgânica e do nitrogênio durante a compostagem da fração sólida do chorume bovino. Revista Brasileira Ciência do Solo, Viçosa-MG, v. 32, p. 1959-1968, 2008.

BUSTAMANTE, M. A.; PAREDES, C.; MARHUENDA-EGEA, F. C.; PÉREZ-ESPINOSA, A.; BERNAL, M. P.; MORAL, R. Co-composting of distillery wastes with animal manures: Carbon and nitrogen transformations in the evaluation of compost stability. Chemosphere, Oxford, v. 72, p. 551-557, 2008.

CARNEIRO, L. J.; DIETER, J.; SAMPAIO, S. C.; SCHMIDT JR, N.; SANTOS-KOELLN, F. T. Balanço de sais provenientes da aplicação de água residuária da suinocultura em quatro ciclos de cultura. Revista e, Agronegócio e Meio Ambiente, Maringá, v. 4, n. 3, p. 481-499, 2011.

CEKMECELIOGLU, D.; DEMERCI, A.; GRAVES, R. E.; DAVITT, N.H. applicability of optimised in-vessel food waste composting for windrow systems. Biosystems Engineering, London, v. 91, p. 479-486, 2005.

COSTA, M. S. S. DE M.; COSTA, L. A. DE M.; SESTAK, M.; OLIBONE, D.; SESTAK, D.; KAUFMANN, A. V.; ROTTA, S. R. Compostagem de resíduos da indústria de desfibrilação de algodão. Engenharia Agrícola, Jaboticabal, v.25, n.2, p.540-548, 2005.

DAL BOSCO, T. C.; IOST, C.; SILVA, L. N.; CARNELOSSI, C. F.; EBERT, D. C.;

SCHREINER, J. S.; SAMPAIO, S. C. Utilização de água residuária de suinocultura em propriedade agrícola - estudo de caso. Revista Irriga, Botucatu, v. 13, n. 1, p. 139-144, jan./mar. 2008.

DAS, K. C.; MINKARA, M. Y. ; MELEAR, M. D.; TOLLNER, E. W. Effect of Poultry Litter Amendment on Hatchery Waste Composting. Journal of Applied Poultry Research, Athens, v. 11, p. 282-290, 2002. 
DOUBLET, J.; FRANCOU, C.; POITREUNAD, M.; HOUOT, S. Influence of bulking agents on organic matter evolution during sewage sludge composting; consequences on compost organic matter stability and N availability. Bioresource Technology, St. Joseph, v.102, p.1298-1307, 2011.

EMBRAPA - Empresa Brasileira de Pesquisa Agropecuária. Embrapa Solos. Embrapa Informática Agropecuária. Manual de análises químicas de solos, plantas e fertilizantes. Brasília, 1999. 370p.

FRIGO, E. P.; SAMPAIO, S. C.; FREITAS, P. L.; NÓBREGA, L. H.; SANTOS, R. F.; MALLMANN, L. S. Desempenho do sistema de gotejamento e de filtros utilizando água residuária da suinocultura. Revista Irriga, Botucatu, v. 11, n. 3, p. 305-318, 2006.

FUKUMOTO, Y.; SUZUKI, K.; KURODA, K.; WAKY, M.; YASUDA, T. Effects of struvite formation and nitratation promotion on nitrogenous emissions such as $\mathrm{NH}_{3}, \mathrm{~N}_{2} \mathrm{O}$ and $\mathrm{NO}$ during swine manure composting. Bioresource Technology, St. Joseph, v.102, p.1468-1474, 2011.

GUARDIA, A.; MALLARD, P.; TEGLIA, C.; MARIN, A.; LE PAPE, C.; LAUNAY, M.;

BENOIST, J. C.; PETIOT, C. Comparison of five organic wastes regarding their behaviour during composting: Part 1, biodegradability, stabilization kinetics and temperature rise. Waste Management, Oxford, v. 30, p. 402-414, 2010a.

GUARDIA, A.; MALLARD, P.; TEGLIA, C.; MARIN, A.; LE PAPE, C.; LAUNAY, M.; BENOIST, J. C.; PETIOT, C. Comparison of five organic wastes regarding their behaviour during composting: Part 2, nitrogen dynamic. Waste Management, Oxford, v. 30, p. 415-425, 2010b.

HAO, X.; BENKE, M.B.; LI, C.; LARNEY, F.J.; BEAUCHEMIN, K.A.; MCALLISTER, T.A. Nitrogen transformations and greenhouse gas emissions during composting of manure from cattle fed diets containing corn dried distillers grains with solubles and condensed tannins. Animal Feed Science and Technology, Amsterdam, v. 166-167, p.539- 549, 2011.

$\mathrm{HAO}, \mathrm{X}$; CHANG, C. Gaseous NO, NO2, and $\mathrm{NH}_{3}$ loss during cattle feedlot manure composting. Phyton-Annales Rei Botanicae, Horn, v. 41, p. 81-93, 2001.

HAROUN, M.; IDRIS, A.; OMAR, S. R. S. A study of heavy metals and their fate in the composting of tannery sludge. Waste Management, Oxford, v. 27, p. 1541-1550, 2007.

HU, T.J.; ZENG, G.M.; HUANG, D.L.; YU, H.Y.; JIANG, X.Y.; DAI, F.; HUANG, G.H. Use of potassium dihydrogen phosphate and sawdust as adsorbents of ammoniacal nitrogen in aerobic composting process. Journal of Hazardous Materials, Amsterdam, v.141, p.736-744, 2007.

JEONG, Y.K.; KIM, J.S. A new method for conservation of nitrogen in aerobic composting process, Bioresource Technology, Essex, v.79, p.129-133, 2001.

JOLANUN, B.; TOWPRAYOON, S. Novel bulking agent from clay residue for food waste composting. Bioresource Technology, Essex, v.101, p.4484-4490, 2010.

KANG, J.; ZHANG, Z.; WANG, J. J. Influence of humic substances on bioavailability of Cu and Zn during sewage sludge composting. Bioresource Technology, Essex, V. 102, p. 8022-8026, 2011.

KIEHL, E. J. Novo fertilizantes orgânicos. Piracicaba: Agronômica Ceres, 2010. 238 p.

LANGSTON, J.; CARMAN,D.; VANDEVENDER, K.; BOLES, J. C. Jr. Disposal of swine carcasses in Arkansas. Arkansas: Cooperative Extension Service, Division of Agriculture, University of Arkansas. Disponível em: <ftp://ftp.uaex.edu/Uploads /Kvan/MortalityCompostingInfo/Disposal\%20of\%20Swine\%20Carcasses\%20in\%20Arkansas\%20 MP392.pdf> . Acesso em: fev. 2013.

LEE, J.E.; RAHMAN, M.M.; RA, C.S. Dose effects of $\mathrm{Mg}$ and $\mathrm{PO}_{4}$ sources on the composting of swine manure. Journal of Hazardous Materials, Amsterdam, v.169, p.801-807, 2009.

LI, X.; ZHANG, R.; PANG, Y. Characteristics of dairy manure composting with rice straw. Bioresource Technology, Essex, v. 99, p. 359-367, 2008. 
LIANG, Y.; LEONARD, J.J.; FEDDES, J.J.R.; MCGILL, W.B. Influence of carbon and buffer amendment on ammonia volatilization in composting. Bioresource Technology, Essex, v. 97, p. 748-761, 2006.

MAGALHÃES, M. A.; DE MATOS, A. T.; WILSON DENÍCULI, W.; TINOCO, I. F. F. Compostagem de bagaço de cana-de-açúcar triturado utilizado como material filtrante de águas residuárias da suinocultura. Revista Brasileira de Engenharia Agrícola e Ambiental, Campina Grande, v.10, n.2, p.466-471, 2006.

MALAVOLTA, E.; VITTI, G.C.; OLIVEIRA, S.A. Avaliação do estado nutricional das plantas: princípios e aplicações. Piracicaba: POTAFOS, 1989. 201 p.

MICHEL JR. F.C.; PECCHIAN, J.S.; RIGOT, J.; KEENER, H.M. Mass and nutrient losses during the composting of dairy manure amended with sawdust and straw. Compost Science Utilization, Emmaus, v.12, p. 323-334, 2004.

MUKHTAR, S.; KALBASI, A.; AHMED, A. Carcass disposal: A comprehensive review. Kansas: Kansas State University, Kansas. 2004.

NEKLYUDOV, A.D., FEDOTOV, G.N., IVANKIN, A.N. Aerobic processing of organic waste into composts. Applied Biochemistry Microbiology, New York, v. 42, p. 341-353, 2006.

ORRICO JÚNIOR, M. A. P; ORRICO, A. C. A.; LUCAS JÚNIOR, J. DE. Compostagem dos resíduos da produção avícola: cama de frangos e carcaças de aves. Engenharia Agrícola, Jaboticabal, v.30, n.3, p.538-545, maio/jun. 2010.

PAGANS, E.; BARRENA, R.; FONT, X.; SÁNCHEZ, A. Ammonia emissions from the composting of of different organic wastes. Dependecy on process temperature. Chemosphere, Oxford, v.62, p.1534-1542, 2006.

PAILLAT, J.M., ROBIN, P., HASSOUNA, M., LETERME, P. Predicting ammonia and carbon dioxide emissions from carbon and nitrogen biodegradability during animal waste composting. Atmospheric Environment, Oxford, v. 39, p. 6833-6842, 2005.

PARKINSON, R., GIBBS, P., BURCHETT, S., MISSELBROOK, T. Effect of turning regime and seasonal weather conditions on nitrogen and phosphorus losses during aerobic composting of cattle manure. Bioresource Technology, Essex, v. 91, p. 171-178, 2004.

PEIGNÉ, J.; GIRARDIN, P. Environmental impacts on farm scale composting practices. Water Air Soil Pollution, New York, v. 153, p. 45-68,2005.

PELISSARI, R.; SAMPAIO, S. C.; GOMES, S. D.; CREPALLI, M. S. Lodo têxtil e água residuária da suinocultura na produção de mudas de eucalyptus grandis (W, Hill ex Maiden). Engenharia Agrícola, Jaboticabal, v. 29, n. 2, p. 288-300, 2009.

RAVIV, M.; MEDINA, S.; KRASNOVSKY, A.; ZIADNA, H. Organic matter and nitrogen conservation in manure compost for organic agriculture. Compost Science Utilization, Emmaus, v. 12, p. 6-10, 2004.

REN, L.M; SCHUCHARDT, F.; SHEN, Y.J.; LI, G.X.; LI, C.P. Impact of struvite crystallization on nitrogen losses during composting of pig manure and cornstalk. Waste Management, Oxford, v.30, p.885-892, 2010.

SAMPAIO S. C.; CAOVILLA, F. A.; OPAZO, M. A. U.; NÓBREGA, L. H. P.; SUSZEK, M.; SMANHOTTO, A. Lixiviação de íons em colunas de solo deformado e indeformado. Engenharia Agrícola, Jaboticabal, v. 30, n. 1, jan./fev. 2010.

SAMPAIO, S. C.; SILVESTRO, M. G.; FRIGO, E. P.; BORGES, C. M. Relação entre série de sólidos e condutividade elétrica em diferentes águas residuárias. Revista Irriga, Botucatu, v. 12, n. 4, p. 557-562, 2007. 
SHEN, Y.; REN, L.; LI, G.; CHEN, T.; GUO, R. Influence of aeration on $\mathrm{CH}_{4}, \mathrm{~N}_{2} \mathrm{O}$ and $\mathrm{NH}_{3}$ emissions during aerobic composting of a chicken manure and high $\mathrm{C} / \mathrm{N}$ waste mixture. Waste Management, Oxford, v. 31, p. 33-38, 2011.

TEJADA, M.; DOBAO, M.M.; BENITEZ, C.; GONZALEZ, J.L. Study of composting of cotton residues Bioresource Technology, Essex, v. 79, p. 199-202, 2001.

TIQUIA, T. M.; TAM, N. F. Y. Characterization and composting of poultry litter in forced-aeration piles. Process Biochemistry, London, v. 37, p. 869-880, 2002.

VERAS, L.R.V.; POVINELLI, J. A vermicompostagem do lodo de lagoas de tratamento de efluentes industriais consorciada com composto de lixo urbano. Revista Brasileira de Engenharia Sanitária e Ambiental, Campina Grande, v. 9, n. 3, p. 218-224, jul/.set. 2004.

WANG, X. D.; CHEN, X. N.; ALI, A. S.; LIU, S.; LU, L. L. Dynamics of Humic SubstanceComplexed Copper and Copper Leaching During Composting of Chicken Manure. Pedosphere, v. 20, n.2, p. 245-251, 2010. 